\title{
Efficacy of Fungicides and Bioagents against Damping off in Chilli caused by Pythium aphanidermatum
}

\author{
A. G. Tekale, D.D. Guldekar, V.P. Kendre*, A.P. Deshmukh and S.R. Potdukhe \\ Department of Plant Pathology, Dr. Panjabrao Deshmukh Krishi Vidyapeeth, \\ Akola (M.S.), India \\ *Corresponding author
}

\begin{tabular}{|c|c|}
\hline & A B S T R A C T \\
\hline $\begin{array}{l}\text { Bioagents, } \\
\text { Capsicum annuum } \\
\text { L., Fungicides, } \\
\text { Pythium }\end{array}$ & \multirow{3}{*}{$\begin{array}{l}\text { Pythium damping-off of Chilli (Capsicum annum L.) is very common problem in fields } \\
\text { and greenhouses, whereas the organism kills newly emerged seedlings. In present } \\
\text { investigation repeated isolations from rotten seeds as well as toppled seedlings of Chilli cv. } \\
\text { Pusa Jwala have yielded the cultures of } P \text {. aphanidermatum. The damping off mainly } \\
\text { being soil borne, the primary infections are needed to be controlled with suitable } \\
\text { fungicides. The different fungicides and bioagents were evaluated as seed dressers and soil } \\
\text { drenching. The result revealed that there was significant difference in per cent disease } \\
\text { incidence at } 15,30 \text { and } 45 \text { day after sowing. Seed dressing of metalaxyl reduced the } \\
\text { damping off disease significantly as compared to all other treatments and at par with } \\
\text { thiram. Among bioagents, Trichoderma harzianum was proved effective in controlling the } \\
\text { disease. In per cent mortality it was found that metalaxyl reduced the plant mortality } \\
\text { significantly over control followed by thiram. Among the bioagents, Trichoderma } \\
\text { harzianum was superior over all other treatments followed by } T \text {. viride. }\end{array}$} \\
\hline Article Info & \\
\hline $\begin{array}{l}\text { Accepted: } \\
\text { 07 May } 2019 \\
\text { Available Online: } \\
\text { 10 June } 2019\end{array}$ & \\
\hline
\end{tabular}

\section{Introduction}

Chilli (Capsicum annuum L.) is an important commercial vegetable crop in India and belongs to Solanaceae family. It is also called as natures wonder, hot pepper, and cayenne pepper. Chilli is the fourth most important vegetable crops in the world and first in Asia. It suffers to various foliar, soil, seed borne and transmissible diseases. The important diseases reported are Anthracnose (Colletotrichum capsici), Cercospora leaf spot (Cercospora capsici), damping-off and root rot (Rhizoctonia solani, Pythium sp., and
Fusarium sp.), Fusarium wilt (Fusarium oxysporum f.sp. capsici), gray mould (Botrytis cinerea), powdery mildew (Leveillula taurica) etc. (Vidhyasekaran and Thiagarajan 1981; Meon and Nick, 1988; pandey et al., 2012; Ahila and Prakasham, 2014). Among these diseases, damping off due to Pythium spp. is of considerable importance.

Most common fungi causing damping off disease are Pythium aphanidermatum, Pythium butleri, Pythium debaryanum and Pythium ultimum. Damping off is responsible 
for poor germination and stand of seedling in nursery bed. Chilli crop suffer from two phases of damping off, one is pre-emergence and another is post-emergence. In preemergence damping off, the young seedlings are killed before they reach the surface of soil. The post-emergence damping off is very conspicuous.

Infection usually occurs at or below ground level and the infected tissue appears water soaked and soft. As the disease advances the stem become constricted at the base and plant collapse. Seedlings that are apparently healthy one day may have collapsed by the following morning (Singh1985). The aim of the present study was to evaluate the efficacy of seed treatments with different fungicides and bioagents either alone or combination against damping-off disease of Chilli plants.

\section{Materials and Methods}

The field experiment was conducted at Plant Pathology Section, College of Agriculture, Nagpur during 2015-16 to find out the effect of different treatment for the management of damping off in Chilli. For this investigation Randomized Block Design was used with three replications and ten treatments were taken.

\section{Seed dressers}

\section{Evaluation of fungicides and bioagents as seed dressers}

The damping off mainly being soil borne, the primary infections are needed to be controlled with suitable fungicides. For testing different fungicides in the sterilized soil the experiment was planned in RBD with 3 replications and 10 treatments. The relative control without seed treatment with inoculation by sterilized soil was maintained. The absolute control without seed treatment, soil inoculation and stagnation was also maintained. For evaluation of different biocontrol agents as seed dressers, seeds of Chilli variety Pusa Jwala were procured. Experiment was conducted in RBD with 3 replications and 10 treatments.

Seeds were treated with following bioagents, one day before sowing. Treated seeds were sown in the sterilized soil in plastic tray. Observations on per cent germination were recorded after $10^{\text {th }}$ days of sowing.

\section{Evaluation of fungicides and biocontrol agents by soil drenching}

For evaluation of fungicides and biocontrol agents by soil drenching, an experiment was planned in Kharif 2015-16 on variety Pusa Jwala. The experiment was planned in R.B.D. with 10 treatments and 3 replications.

The formulation required in gram per liter was calculated by using the following formula,

$\mathrm{M}_{\mathrm{f}}=\frac{\mathrm{Cx} \mathrm{V}}{-\mathrm{A} \text {. I. }(\%)}$

Where,

$\mathrm{M}_{\mathrm{f}}=$ Mass of formulation required in gram $\mathrm{C}=$ Concentration of the A.I. desired.

$\mathrm{V}=$ Volume of the solution/medium to be prepared.

A.I. $(\%)=$ Percentage of Active Ingredient in formulation.

\section{Evaluation of fungicides and bioagents in vitro}

Efficacy of (Five) fungicides and (Three) bioagents were evaluated by employing poisoned food technique and dual culture technique respectively. 
In vitro efficacy of fungicides against Pythium aphanidermatum by poisoned food technique

Efficacies of five fungicides were evaluated in vitro against Pythium aphanidermatum by poisoned food technique. Based on active ingredient, the requisite quantity of each fungicide was calculated and mixed thoroughly with autoclaved and cooled Potato Dextrose Agar medium (PDA) in conical flask to obtain desired concentrations. Plain PDA medium without fungicides served as untreated control. Fungicide amended PDA medium was then poured aseptically in petriplates $(90 \mathrm{~mm}$ diameter) and allowed to solidify at room temperature. After solidification of the medium, all the plates were inoculated aseptically with $4 \mathrm{~mm}$ culture disc of the test fungus obtained from a week old actively growing pure culture of Pythium aphanidermatum.

The disc was placed on PDA in the centre of the petriplates and the plates were incubated at $27 \pm 1^{\circ} \mathrm{C}$. Each treatment was replicated thrice. Observations on radial mycelial growth/colony diameter were recorded on $3^{\text {rd }}$, $5^{\text {th }}$ and $7^{\text {th }}$ days after inoculation. Per cent mycelial growth inhibition of the test pathogen with the test fungicides over untreated control was calculated by applying the formula given below based on the average of colony diameter. The data of mycelial growth was also subjected to statistical analysis and conclusions were drawn (Gomez and Gomez, 1984).

Percent inhibition $(I)=\frac{\mathrm{C}-\mathrm{T}}{\mathrm{C}} 100$

Where,

$\mathrm{C}=$ Growth (mm) of test fungus in untreated control plates
$\mathrm{T}=$ Growth $(\mathrm{mm})$ of test fungus in treated plates

\section{In vitro evaluation of bioagents by dual culture technique}

Antagonistic activity of Trichoderma viride, Trichoderma harzianum and Pseudomonas fluorescens on growth of Pythium aphanidermatum was studied by dual culture technique on PDA plates. Discs of $4 \mathrm{~mm}$ of Pythium aphanidermatum were placed at center of respective PDA plates. Then bacterial antagonists were streaked on side of fungal pathogens leaving $3 \mathrm{~cm}$ distances between them. In case of fungal antagonist each plate was inoculated with $4 \mathrm{~mm}$ mycelial disc of fungal pathogens and Trichoderma viride were placed at side by side on medium in each plate approximately at a distance of 4 $\mathrm{cm}$ away from each other. Similarly one set of each fungus without any bioagents culture served as control.

The inoculated plates were incubated at $28 \pm 2^{\circ} \mathrm{C}$ for 3 days in case of Pythium aphanidermatum. Observations regarding antagonistic effect of all these bioagents against test pathogens were recorded at $3^{\text {rd }}, 5^{\text {th }}$ and $7^{\text {th }}$ days after inoculation. After $3^{\text {rd }}$ and $7^{\text {th }}$ days of incubation as mentioned earlier colony diameter of test fungus in each plate was measured and mean diameter and per cent inhibition in each case was worked out. The growth inhibition of each fungal pathogen was calculated by using the formula given below by Anand et al., 2010 as follows,

Per cent inhibition $(I)=\frac{\text { C-T }}{\text { C }-------}$ x 100

Where,

$\mathrm{C}=$ Colony diameter in control. $\mathrm{T}=$ Colony growth in treatment. 


\section{Results and Discussion}

\section{Effect of seed dresser on seed germination}

The data from Table 1 indicated that the highest seed germination was recorded with metalaxyl (87.22 per cent) at par with thiram (81.36 per cent). Among fungicides, the lowest per cent seed germination was recorded in carbendazim (68.24 per cent). Among the bioagents, the highest seed germination was recorded by Trichoderma harzianum 69.21 per cent at par with Trichoderma viride (56.18 per cent). This was followed by Pseudomonas fluorescens (50.33 per cent).

The present results are in argument with the findings of Zagade et al., (2012) who reported metalaxyl alone or in combination with $\mathrm{T}$. hamatum has synergistic effect for reducing the seed rot and improving the germination and was used against Oomycetes fungi like Pythium @ 3g/ kg seed. And thiram, captan, carbendazim were at par and were inferior to metalaxyl $+T$. hamatum and metalaxyl alone. Muthukumar et al., (2010) reported significant increase in the germination, shoot length and root length of Chilli plants. Chakraborty et al., (2005) recorded the maximum seed germination $(86 \%)$ and minimum pre and post damping off in brinjal. Similar studies were given by Deshmukh et al., (2012), Ghutukade et al., (2013), Manoranjitham et al., (2000), Bohra et al., (2006), Korekar et al., (1992), Thakur and Tripathi (2015), Zalte et al., (2013) and Kaiser et al., (1983).

\section{Effect of soil drenching on seed germination}

The data from Table 2 revealed that the metalaxyl was most effective in increasing the seed germination by 79.35 per cent over control and at par with thiram (74.23 per cent), followed by captan (68.51 per cent), chlorothalonil (61.19 per cent) and carbendazim (57.44 per cent). The lowest per cent seed germination was recorded in control (41.12 per cent). Among the bioagents, the highest seed germination was recorded with Trichoderma harzianum (54.21 per cent) at par with Trichoderma viride (49.64 per cent) and Pseudomonas fluorescens (46.33 per cent).

The above results were also in agreement with the findings of Rathaiah (1982), Kurucheve and Padmavathi (1998), Chakraborty et al., (2005), Ganeshan and Sinha (2002) and Manoranjitham et al., (2001) (Table 3 and 4).

\section{Disease incidence of pre emergence damping off}

It is evident from the Table 5 that significant reduction in pre emergence damping off of chilli was recorded in metalaxyl (31.92 per cent), which was significanty superior to all other treatments. The treatment thiram (49.72 per cent) was at par with captan (55.51 per cent) and chlorothalonil (59.60 per cent). Higher pre emergence damping off disease was recorded in inoculated control (72.11 per cent). Among the bioagents, Trichoderma harzianum recorded less disease incidence (53.58 per cent) and at par with Trichoderma viride (57.26 per cent) and Pseudomonas fluorescens (67.38 per cent).

The present results are similar with the finding of Zagade et al., (2012) who concluded that Metalaxyl $+T$. hamatum seed treatment was significantly superior over rest of the fungicides tested. Metalaxyl alone ranked $2^{\text {nd }}$. Metalaxyl alone was also significantly superior over rest of the fungicide tested. Cyamoxanil $+T$. hamatum was at par with metalaxyl alone (on basis of percentage value) reported by Thakur and Tripathi (2015), Deshmukh et al., (2012) and Muthukumar et al., (2011). 
Disease incidence of post emergence damping off

It is evident from Table 6 that there was significant difference in incidence of damping off disease due to various treatments at 15, 30 and 45 days over control. At 15 DAS the effect of metalaxyl @ $0.2 \%$ was found in minimising disease incidence ( 10.81 per cent) and at par with thiram @ $0.3 \%$ treatment (15.38 per cent) and captan @ $0.3 \%$ treatment (16.00 per cent). This was followed by chlorothalonil (18.18 per cent) and carbendazim (23.80 per cent). Among the bioagents, Trichoderma harzianum $(25.00$ per cent) was significantly superior followed by Trichoderma viride and Pseudomonas fluorescens $(30.43, \quad 35.00$ per cent respectively).

Result of this experiment was similar with the results recorded by Muthukumar et al., (2011), Muthukumar et al., (2010), who reported minimum pre and post emergence damping off of $(9.10$ and 12.33 per cent respectively), which was on par with metalaxyl treatment. Saha et al., (2008), Usharani and Satheesh (2007), reported that thiram recorded lowest disease incidence. Sharma and Sain (2005), Jain et al., (2014), Thakur and Tripathi (2015), Manoranjitham and Prakasam (1999) reported that $T$. harzianum and $T$. viride effectively reduced the pre and post emergence damping off. At 30 and 45 DAS metalaxyl treatments recorded minimum percent disease incidence $(13.51 \%$ and $18.71 \%)$ and at par with thiram (19.23\% and $23.07 \%$ ), captan $(20.00 \%$ and $28.00 \%)$ and chlorothalonil (22.72\% and $31.18 \%)$ followed by carbendazim $(33.33 \%$ and $38.09 \%$ ). Among the bioagents, Trichoderma harzianum recorded less disease incidence $(37.50 \%$ and $41.66 \%)$ and at par with Trichoderma viride $(43.47 \%$ and $47.82 \%)$ and Pseudomonas fluorescens $(45.00 \%$ and $56.09 \%$ respectively).
The present results are similar with findings of Sawant and Mukhopadhyay (1990) who reported seed treatment with $1000 \mathrm{ppm}$ metalaxyl gave complete protection against damping off for entire period. Salman and Abuamsha (2012) reported that the metalaxyl$\mathrm{M}$ treatment applied alone or in combination with $P$. fluorescencs, significantly protected tomato seedling against damping off. Ghutukade et al., (2013) reported that metalaxyl showed maximum reduction in damping off (4.44 per cent) in nursery. Saha et al., (2008) found that thiram was proved superior to captan and loss recorded was (13.7 per cent) and (18.35 per cent) respectively. Deshmukh et al., (2012) and Mehetre and kale (2011) recorded T. harzianum seed treatment, with corresponding significantly highest reduction in post emergence followed by Trichoderma viride and Pseudomonas fluorescencs respectively. Dar et al., (2012) showed damping off of papaya caused by Pythium debaryanum was reduced by soil and seed application of talc based formulation of $P$. fluorescencs. The antagonistics and chemical metalaxyl increased the seed germination, shoot length, root length, fresh and dry weight of papaya seedlings.

\section{Mortality in soil drenching}

The data regarding the mortality presented in Table 7 indicated significant difference due to various treatments over control. Among the treatments, it was found that metalaxyl (10.36 per cent) reduced the plant mortality significantly over control. Followed by thiram (17.87 per cent), captan (23.85 per cent), chlorothalonil (25.54 per cent) and carbendazim (31.82 per cent). All these treatments were statistically at par with each other. Among the bioagents, Trichoderma harzianum (35.27per cent) is superior to all other treatments followed by $T$. viride and $P$. fluorescens (37.27per cent and 48.50 per cent respectively). 
The present results are similar with the findings of Zagade et al., (2012) who reported that drenching with either metalaxyl or cymoxanil reduced the plant mortality significantly over control and rest of the fungicides tested. Metalaxyl and cymoxanil were at par in reducing the percent mortality. Jahagirdar (2012) found that the drenching with metalaxyl-M + mancozeb reduced minimum disease incidence. Rathaiah (1982) reported that the soil drenching with Ridomil, reduced the incidence of rhizome rot as compared to control. Deshpande (1985) concluded that only metalaxyl could protect the seedling from post emergence mortality followed by captan and thiram. Manoranjitham et al., (2000) reported soil application of $T$. viride and $P$. fluorescens effectively checked the pre and post emergence damping off of tomato. Hegde and Kulkarni (2001) revealed that captan, thiram, $T$. harzianum and $P$. fluorescens reduced the damping off of seedling to the maximum extent, thus can minimize the secondary spread of the inoculum. Kanse et al., (2011) recorded that $T$. harzianum was superior followed by $P$. fluorescencs and $T$. viride.

Table.1 Seed dressers

\begin{tabular}{|c|l|l|}
\hline Treatment No. & \multicolumn{1}{|c|}{ Treatments details } & Doses \\
\hline $\mathbf{T}_{\mathbf{1}}$ & MetalaxyI 35\% SD & $0.2 \%$ \\
\hline $\mathbf{T}_{\mathbf{2}}$ & Captan 75\%WP & $0.3 \%$ \\
\hline $\mathbf{T}_{\mathbf{3}}$ & Thiram 75\% WP & $0.3 \%$ \\
\hline $\mathbf{T}_{\mathbf{4}}$ & Carbendazim 50\%WP & $0.1 \%$ \\
\hline $\mathbf{T}_{\mathbf{5}}$ & Chlorothalonil 78\% WP & $0.3 \%$ \\
\hline $\mathbf{T}_{\mathbf{6}}$ & Trichoderma viride $\left(10^{7} \mathrm{cfu}\right)$ & $4 \mathrm{~g} / \mathrm{kg}$ \\
\hline $\mathbf{T}_{\mathbf{7}}$ & Trichoderma harzianum $\left(10^{7} \mathrm{cfu}\right)$ & $4 \mathrm{~g} / \mathrm{kg}$ \\
\hline $\mathbf{T}_{\mathbf{8}}$ & Pseudomonas fluorescens $\left(10^{8} \mathrm{cfu}\right)$ & $4 \mathrm{~g} / \mathrm{kg}$ \\
\hline $\mathbf{T}_{\mathbf{9}}$ & Uninoculated control & - \\
\hline $\mathbf{T}_{\mathbf{1 0}}$ & Inoculated control & - \\
\hline
\end{tabular}

Table.2 Soil drenching

\begin{tabular}{|l|l|l|}
\hline Treatment No. & Treatments details & $\begin{array}{l}\text { Rate of application } \\
\text { (g/kg) }\end{array}$ \\
\hline $\mathbf{T}_{\mathbf{1}}$ & MetalaxyI 35\% SD & 2 \\
\hline $\mathbf{T}_{\mathbf{2}}$ & Captan 75\%WP & 3 \\
\hline $\mathbf{T}_{\mathbf{3}}$ & Thiram 75\% WP & 3 \\
\hline $\mathbf{T}_{\mathbf{4}}$ & Carbendazim 50\%WP & 1 \\
\hline $\mathbf{T}_{\mathbf{5}}$ & Chlorothalonil 78\% WP & 3 \\
\hline $\mathbf{T}_{\mathbf{6}}$ & Trichoderma viride & $1 \times 10^{7} \mathrm{cfu} / \mathrm{ml}$ \\
\hline $\mathbf{T}_{\mathbf{7}}$ & Trichoderma harzianum & $1 \times 10^{7} \mathrm{cfu} / \mathrm{ml}$ \\
\hline $\mathbf{T}_{\mathbf{8}}$ & Pseudomonas fluorescens & $1 \times 10^{8} \mathrm{cfu} / \mathrm{ml}$ \\
\hline $\mathbf{T}_{\mathbf{9}}$ & Uninoculated Control & - \\
\hline $\mathbf{T}_{\mathbf{1 0}}$ & Inoculated Control & - \\
\hline
\end{tabular}


Table.3 Effect of seed treatment with fungicides and bioagents on per cent seed germination

\begin{tabular}{|c|l|c|}
\hline Treatment No. & Treatments Details & Seed germination $(\mathbf{\%})$ \\
\hline $\mathbf{T}_{\mathbf{1}}$ & Metalaxyl & $87.22^{* *}$ \\
\hline $\mathbf{T}_{\mathbf{2}}$ & Captan & 76.40 \\
\hline $\mathbf{T}_{\mathbf{3}}$ & Thiram & $81.36^{*}$ \\
\hline $\mathbf{T}_{\mathbf{4}}$ & Carbendazim & 68.24 least \\
\hline $\mathbf{T}_{\mathbf{5}}$ & Chlorothalonil & 72.04 \\
\hline $\mathbf{T}_{\mathbf{6}}$ & Trichoderma viride $\left(10^{7} \mathrm{cfu}\right)$ & $56.18^{*}$ \\
\hline $\mathbf{T}_{\mathbf{7}}$ & Trichoderma harzianum $\left(10^{7} \mathrm{cfu}\right)$ & $69.21^{* *}$ \\
\hline $\mathbf{T}_{\mathbf{8}}$ & Pseudomonas fluorescens $\left(10^{8} \mathrm{cfu}\right)$ & 50.33 \\
\hline $\mathbf{T}_{\mathbf{9}}$ & Uninoculated Control & 91.18 \\
\hline $\mathbf{T}_{\mathbf{1 0}}$ & Inoculated Control & 44.37 \\
\hline & 'F' Test & Sig. \\
\hline & SE $\pm(m)$ & $\mathbf{3 . 8 7}$ \\
\hline & CD $(\mathrm{P}=0.05)$ & $\mathbf{1 5 . 7 7}$ \\
\hline
\end{tabular}

Table.4 Effect of soil drenching with fungicides and bioagents on per cent seed germination

\begin{tabular}{|c|l|c|}
\hline Treatment No. & Treatments Details & Seed germination $(\%)$ \\
\hline $\mathbf{T}_{\mathbf{1}}$ & Metalaxyl & $79.35 * *$ \\
\hline $\mathbf{T}_{\mathbf{2}}$ & Captan & 68.51 \\
\hline $\mathbf{T}_{\mathbf{3}}$ & Thiram & $74.23^{*}$ \\
\hline $\mathbf{T}_{\mathbf{4}}$ & Carbendazim & 57.44 \\
\hline $\mathbf{T}_{\mathbf{5}}$ & Chlorothalonil & 61.19 \\
\hline $\mathbf{T}_{\mathbf{6}}$ & Trichoderma viride $\left(10^{7} \mathrm{cfu}\right)$ & 49.64 \\
\hline $\mathbf{T}_{\mathbf{7}}$ & Trichoderma harzianum $\left(10^{7} \mathrm{cfu}\right)$ & $54.21^{* *}$ \\
\hline $\mathbf{T}_{\mathbf{8}}$ & Pseudomonas fluorescens $\left(10^{8} \mathrm{cfu}\right)$ & $46.33^{*}$ \\
\hline $\mathbf{T}_{\mathbf{9}}$ & Uninoculated Control & 83.05 \\
\hline $\mathbf{T}_{\mathbf{1 0}}$ & Inoculated Control & 41.12 lowest \\
\hline & 'F' Test & Sig. \\
\hline & SE $\pm(m)$ & $\mathbf{3 . 4 3}$ \\
\hline & CD $(\mathrm{P}=0.05)$ & $\mathbf{1 0 . 2 6}$ \\
\hline
\end{tabular}


Table.5 Effect of sees treatment with fungicides and bioagents on pre emergence damping off

\begin{tabular}{|c|c|c|}
\hline Treatment No. & Treatments Details & $\%$ Incidence \\
\hline $\mathrm{T}_{1}$ & Metalaxyl & $\begin{array}{l}31.92 \\
(34.40)^{*}\end{array}$ \\
\hline $\mathbf{T}_{2}$ & Captan & $\begin{array}{l}55.16 \\
(47.96)^{*}\end{array}$ \\
\hline $\mathbf{T}_{3}$ & Thiram & $\begin{array}{l}49.72 \\
(44.84)^{*}\end{array}$ \\
\hline $\mathbf{T}_{4}$ & Carbendazim & $\begin{array}{l}68.79 \\
(56.04)^{*}\end{array}$ \\
\hline $\mathbf{T}_{5}$ & Chlorothalonil & $\begin{array}{l}59.60 \\
(50.53)^{*}\end{array}$ \\
\hline $\mathbf{T}_{6}$ & Trichoderma viride $\left(10^{7} \mathrm{cfu}\right)$ & $\begin{array}{l}57.26 \\
(49.17)^{*}\end{array}$ \\
\hline $\mathbf{T}_{7}$ & Trichoderma harzianum $\left(10^{7} \mathrm{cfu}\right)$ & $\begin{array}{l}53.58 \\
(47.05)^{*}\end{array}$ \\
\hline $\mathbf{T}_{8}$ & Pseudomonas fluorescens $\left(10^{8} \mathrm{cfu}\right)$ & $\begin{array}{l}67.38 \\
(55.17)^{*}\end{array}$ \\
\hline $\mathbf{T}_{9}$ & Uninoculated Control & $\begin{array}{l}02.86 \\
(09.74)^{*}\end{array}$ \\
\hline \multirow[t]{4}{*}{$\mathbf{T}_{10}$} & Inoculated Control & $\begin{array}{l}72.11 \\
(58.12)^{*}\end{array}$ \\
\hline & 'F' Test & Sig. \\
\hline & $\mathrm{SE} \pm(\mathrm{m})$ & 2.96 \\
\hline & $\mathrm{CD}(\mathrm{P}=0.05)$ & 8.86 \\
\hline
\end{tabular}

*(Figures in parentheses are Arc sine transformed values)

Table.6 Effect of fungicides and bioagents on post emergence damping off

\begin{tabular}{|c|l|l|l|l|}
\hline Treatment No. & Treatments details & \multicolumn{3}{l|}{ Percent disease incidence } \\
\cline { 3 - 5 } & & 15DAS & 30DAS & 45DAS \\
\hline $\mathbf{T}_{\mathbf{1}}$ & Metalaxyl & 10.81 & 13.51 & 18.71 \\
& & $(19.20)^{*}$ & $(21.57)^{*}$ & $(25.63)^{*}$ \\
\hline $\mathbf{T}_{\mathbf{2}}$ & Captan & 16.00 & 20.00 & 28.00 \\
& & $(23.58)^{*}$ & $(26.57)^{*}$ & $(31.95)^{*}$ \\
\hline $\mathbf{T}_{\mathbf{3}}$ & Thiram & 15.38 & 19.23 & 23.07 \\
& & $(23.09)^{*}$ & $(26.01)^{*}$ & $(28.71)^{*}$ \\
\hline $\mathbf{T}_{\mathbf{4}}$ & Carbendazim & 23.80 & 33.33 & 38.09 \\
& & $(29.20)^{*}$ & $(35.26)^{*}$ & $(38.11)^{*}$ \\
\hline $\mathbf{T}_{\mathbf{5}}$ & Chlorothalonil & 18.18 & 22.72 & 31.18 \\
& & $(25.24)^{*}$ & $(28.47)^{*}$ & $(33.94)^{*}$ \\
\hline $\mathbf{T}_{\mathbf{6}}$ & Trichoderma viride $\left(10^{7} \mathrm{cfu}\right)$ & 30.43 & 43.47 & 47.82 \\
& & $(33.48)^{*}$ & $(41.25)^{*}$ & $(43.75)^{*}$ \\
\hline $\mathbf{T}_{\mathbf{7}}$ & Trichoderma harzianum $\left(10^{7} \mathrm{cfu}\right)$ & 25.00 & 37.50 & 41.66 \\
& & $(30.00)^{*}$ & $(37.76)^{*}$ & $(40.20)^{*}$ \\
\hline $\mathbf{T}_{\mathbf{8}}$ & Pseudomonas fluorescens $\left(10^{8} \mathrm{cfu}\right)$ & 35.00 & 45.00 & 56.09 \\
& & $(36.27)^{*}$ & $(42.13)^{*}$ & $(48.50)^{*}$ \\
\hline $\mathbf{T}_{\mathbf{9}}$ & Uninoculated Control & 01.40 & 02.68 & 04.22 \\
& & $(06.80)^{*}$ & $(09.42)^{*}$ & $(11.85)^{*}$ \\
\hline $\mathbf{T}_{\mathbf{1 0}}$ & Inoculated Control & 63.93 & 69.42 & 70.40 \\
& & $(53.09)^{*}$ & $(56.43)^{*}$ & $(57.04)^{*}$ \\
\hline & 'F' Test & Sig. & Sig. & Sig. \\
\hline & SE \pm (m) & $\mathbf{1 . 6 4}$ & $\mathbf{1 . 9 8}$ & $\mathbf{2 . 1 9}$ \\
\hline & CD (P=0.05) & $\mathbf{4 . 9 2}$ & $\mathbf{5 . 9 5}$ & $\mathbf{6 . 5 6}$ \\
\hline
\end{tabular}

*(figures in parentheses are Arc sine transformed values) 
Table.7 Effect of soil drenching with fungicides and bioagents on per cent mortality in damping off

\begin{tabular}{|c|c|c|c|}
\hline \multirow[t]{2}{*}{ Treatment No. } & \multirow[t]{2}{*}{ Treatments details } & \multicolumn{2}{|c|}{ Per cent Mortality } \\
\hline & & 20 DAS & 30 DAS \\
\hline $\mathbf{T}_{1}$ & Metalaxyl & $\begin{array}{l}07.23 \\
(15.60)^{*}\end{array}$ & $\begin{array}{l}10.36 \\
(18.78)^{*}\end{array}$ \\
\hline $\mathbf{T}_{2}$ & Captan & $\begin{array}{l}20.67 \\
(27.04) *\end{array}$ & $\begin{array}{l}23.85 \\
(29.23)^{*}\end{array}$ \\
\hline $\mathbf{T}_{3}$ & Thiram & $\begin{array}{l}16.38 \\
(23.87)^{*}\end{array}$ & $\begin{array}{l}17.87 \\
(25.01)^{*}\end{array}$ \\
\hline $\mathbf{T}_{4}$ & Carbendazim & $\begin{array}{l}27.84 \\
(31.85)^{*}\end{array}$ & $\begin{array}{l}31.82 \\
(34.34)^{*}\end{array}$ \\
\hline $\mathbf{T}_{5}$ & Chlorothalonil & $\begin{array}{l}23.72 \\
(29.85)^{*}\end{array}$ & $\begin{array}{l}25.54 \\
(30.36)^{*}\end{array}$ \\
\hline $\mathbf{T}_{6}$ & Trichoderma viride $\left(10^{7} \mathrm{cfu}\right)$ & $\begin{array}{l}36.44 \\
(37.13)^{*}\end{array}$ & $\begin{array}{l}37.27 \\
(37.63) *\end{array}$ \\
\hline $\mathbf{T}_{7}$ & Trichoderma harzianum $\left(10^{7} \mathrm{cfu}\right)$ & $\begin{array}{l}31.12 \\
(33.91)^{*}\end{array}$ & $\begin{array}{l}35.27 \\
(36.43)^{*}\end{array}$ \\
\hline $\mathbf{T}_{8}$ & Pseudomonas fluorescencens $\left(10^{8} \mathrm{cfu}\right)$ & $\begin{array}{l}46.08 \\
(42.75)^{*}\end{array}$ & $\begin{array}{l}48.50 \\
(44.14)^{*}\end{array}$ \\
\hline $\mathbf{T}_{9}$ & Uninoculated Control & $\begin{array}{l}02.19 \\
(08.51)^{*}\end{array}$ & $\begin{array}{l}04.62 \\
(12.41)^{*}\end{array}$ \\
\hline $\mathbf{T}_{10}$ & Inoculated Control & $\begin{array}{l}73.41 \\
(58.96)^{*}\end{array}$ & $\begin{array}{l}76.54 \\
(61.03)^{*}\end{array}$ \\
\hline & 'F' Test & Sig. & Sig. \\
\hline & $\mathrm{SE} \pm(\mathrm{m})$ & 1.93 & 2.05 \\
\hline & $\mathrm{CD}(\mathrm{P}=0.05)$ & 5.78 & 6.16 \\
\hline
\end{tabular}

*(Figures in parentheses are Arc sine transformed values)

Table.8 In vitro effect of fungicides and bioagents on radial mycelial growth at $7^{\text {th }}$ DAI

\begin{tabular}{|l|l|l|l|l|}
\hline $\begin{array}{l}\text { Treatment } \\
\text { No. }\end{array}$ & Treatment details & $\begin{array}{l}\text { Conc. } \\
\mathbf{\%}\end{array}$ & $\begin{array}{l}\text { Mean } \\
\text { diameter (mm) }\end{array}$ & $\begin{array}{l}\text { Pelony } \\
\text { growth } \\
\text { inhibition }\end{array}$ \\
\hline $\mathbf{T}_{\mathbf{1}}$ & Metalaxyl & 0.2 & 00 & $\begin{array}{l}100 \\
(90.00)^{*}\end{array}$ \\
\hline $\mathbf{T}_{\mathbf{2}}$ & Captan & 0.3 & 16.32 & $\begin{array}{l}79.43 \\
(63.02)^{*}\end{array}$ \\
\hline $\mathbf{T}_{\mathbf{3}}$ & Thiram & 0.3 & 11.22 & $\begin{array}{l}85.66 \\
(67.74)^{*}\end{array}$ \\
\hline $\mathbf{T}_{\mathbf{4}}$ & Carbendazim & 0.1 & 22.17 & $\begin{array}{l}72.66 \\
(58.47)^{*}\end{array}$ \\
\hline $\mathbf{T}_{\mathbf{5}}$ & Chlorothalonil & 0.3 & 18.64 & $\begin{array}{l}76.24 \\
(60.82)^{*}\end{array}$ \\
\hline $\mathbf{T}_{\mathbf{6}}$ & Trichoderma viride & - & 30.43 & $\begin{array}{l}61.65 \\
(51.73)^{*}\end{array}$ \\
\hline $\mathbf{T}_{\mathbf{7}}$ & Trichoderma harzianum & - & 26.12 & $\begin{array}{l}67.65 \\
(55.33)^{*}\end{array}$ \\
\hline $\mathbf{T}_{\mathbf{8}}$ & Pseudomonas fluorescens & - & 32.29 & $\begin{array}{l}59.23 \\
(50.31)^{*}\end{array}$ \\
\hline $\mathbf{T}_{\mathbf{9}}$ & Control & & 79.35 & \\
\hline & 'F' Test & Sig. & \\
\hline & SE \pm (m) & $\mathbf{1 . 9 8}$ & \\
\hline & CD (P=0.01) & $\mathbf{8 . 1 6}$ & \\
\hline
\end{tabular}

*(Figures in parentheses are Arc sine transformed values) 


\section{Evaluation of fungicides and bioagents on} in vitro

Observation on average colony diameter at $7^{\text {th }}$ day after inoculation and per cent growth inhibition was recorded. The fungicides and bioagents showed their potentiality to check the mycelial growth of pathogen Pythium spp.

The data presented in Table 1, fungicides viz., Metalaxyl, Captan, Thiram, Carbendazim, Chlorothalonil, and biocontrol agents like Trichoderma viride, Trichoderma harzianum and Pseudomonas fluorescens were evaluated at recommended concentration in the laboratory for their efficacy against Pythium aphanidermatum by applying poisoned food technique and dual culture technique.

Fungicides and bioagents significantly inhibited the growth of Pythium aphanidermatum. Fungicides like metalaxyl was found significantly superior to arrest the growth of pathogen with (100 per cent) inhibition followed by thiram which was recorded (85.66 per cent) growth inhibition over control (Table 8). Lowest per cent growth inhibition was observed in carbendazim (72.66 per cent) as compared to control. The above results correlated with the results recorded by Yadav and Joshi (2012), Gupta et al., (2012), Gholve et al., (2014) and Zalte et al., (2013). Among the bioagents Trichoderma harzianum recorded (67.65 per cent) growth inhibition as compared to Trichoderma viride (61.65 per cent) and Pseudomonas fluorescens (59.23 per cent). The present results are similar with the findings of Muthukumar et al., (2010), Ramamoorthy et al., (2002), Muthukumar (2011), Gulhane et al., (2005) and Sushir et al., (2006).

\section{References}

Bohra, B., B. N. Vyas and K. B. Mistry, 2006.
Biocontrol agent and neem formation for management of damping off in brinjal and chilli. Indian Phytopathol. 59 (2): 223-226.

Chakraborty, A., S. Das, B. K. Manna, A. Basa and S. K. Raj, 2005. Bioantagonist combinations against Pythium damping off of Brinjal. J. Mycol. Pl. Pathol. 35 (3): 537.

Dar, W. A., J. A. Bhat, R. Rashid, S. Rehman and Z. A. Bhat, 2012. Bioefficacy of Pseudomonas fluorescens in management of damping-off disease in papaya (Carica papaya L.). J. Agri. Tech. 8 (2): 693-697.

Deshmukh, R. R., K. T. Apet, H. N. Kamble and U. Dey, 2012. Effect of different bio-inoculants on germination and biometric characters of chilli (var. parbhani tejas). Int. J. Pl. Protec. 5 (2): 252-255.

Deshpande, G. D., 1985. Susceptible stages of cucumber to post emergence damping off and fungicidal efficacy against Pythium ultimum Trow. Indian $J$. Mycol. Pl. Pathol. 3 (16): 326-328.

Ganeshan, G. and P. Sinha, 2002. Control of damping off in tomato nursery using biocontrol agents and chemicals. Indian Phytopathol. 55 (3): 389.

Gholve, V. M., V. R. Tatikundalwar, A. P. Suryawanshi and U. Dey, 2014. Effect of fungicides, plant extracts / botanicals and bioagents against damping off in brinjal. African. $J$. Microbiol. Res. 8 (30): 2835-2848.

Ghutukade, K. S., A. Laland and S. A. Raut, 2013. Effect of seed treatment with fungicides and bio-agents on damping off of chilli caused by Pythium aphanidermatum. Trends in Biosci. 6 (4): 490-493.

Gulhane, V. G., S. J. Gailwad, P. W. Lanje, S. R. Zade and V. B. Kueuwanshi, 2005 a. In vitro study of antagonistic effect of bioagents on damping off pathogen 
of tomato. J. Soil crop. 15 (1): 173 176.

Gulhane, V. G., S. J. Gailwad, P. W. Lanje, S. R. Zade and V. B. Kueuwanshi, 2005

b. Biological control of damping off of tomato caused by Pythium aphanidermatum (Eds.) Fitz. J. Soil crop. 15 (1): 118-121.

Gupta, V., V. K. Razdan and R. singh, 2012. Evaluation of fungicides and antibiotics against soil born pathogen of brinjal. J. Mycopathol. Res. 50 (2): 229-233.

Hegde, G. M. and S. Kulkarni, 2001. Seed treatment to control damping off of chilli caused by Colletotrichum capsici. Karanatka J. Agri. Sci. 14 (3): 829-830.

Jahagirdar, S., 2012. Management of damping off of tobacco in the nursery bed with fungicides. Indian Phytopatol. 65 (2): 206-207.

Kaiser, W. J. and R. M. Hannan, 1983. Etiology and control of seed decay and pre-emergence damping off of chickpea by Pythium ultimum. Pl. Dis. 67: 77-81.

Kanse, R. V., Y. T. Jadhav, D. T. Jagatap and D. S. Thaware, 2011. Effect of seed treatment with bio-agents and chemicals in management of nursery disease in tomato. Int. J. Pl. Protec. 4 (1): 53-54.

Korekar, V. B., C. U. Patil and R. B. Somani, 1992. Efficiency of different fungicides, $\mathrm{V}$. chilli damping off. $P K V$ Res. J. 16 (1): 124-125.

Kurucheve, V. and R. Padmavathi, 1998. Management of damping off of chilli with plant products. Indian Phytopathol. 51 (3): 379-381.

Manoranjitham, S. K. and V. Prakasam, 1999. Management of chilli damping off using biocontrol agents. Capsicum Eggplant News Lett. 19: 101-104.

Manoranjitham, S. K., V. Prakasam and K.
Rajappan, 2001. Biocontrol of damping off of tomato caused by Pythium aphanidermatum. Indian Phytopathol. 54 (1): 59-61.

Manoranjitham, S. K., V. Prakasam, K. Rajappan and G. Amutha, 2000 a. Control of chilli damping off using bioagents. J. Mycol. Pl. Pathol. 30 (2): 225-228.

Manoranjitham, S. K., V. Prakasam, K. Rajappan and G. Amutha, 2000 b. Effect of two antagonists on damping off disease of tomato. Indian Phytopathol. 53 (4): 441-443.

Mehetre, S. T. and S. P. Kale, 2011. Comparative efficacy of thermophilic bacterium, Bacillus licheniformis (NR1005) and antagonistic fungi, Trichoderma harzianum to control Pythium aphanidermatum induced damping off in chilli (Capsicum annuum L.). Arch. Phytopathol. Pl. Protec. 44 (11): 1068-1074.

Muthukumar, A., 2011. Evaluation of introduced Trichoderma species as antagonist of Pythium aphanidermatum causing chilli damping-off. Pl. Dis. Res. 26 (2): 136138.

Muthukumar, A., R. Bhaskaran and K. Sanjeevkumar, 2010. Efficacy of endophytic Pseudomonas fluorescens (Trevisan) migula against chilli damping-off. J. Biopest. 3 (1): 105109.

Ramamoorthy, V., T. Raguchander and R. Samiyappan, 2002. Enhancing resistance of tomato and hot pepper to Pythium diseases by seed treatment with fluorescent pseudomonas. European J. Pl. Pathol. 108: 429-441.

Rathaiah, Y., 1982. Ridomil for control of rhizome rot of turmeric. Indian Phytopathol. 35 (2): 297-299.

Saha, S., I. Naskar, D. K. Nayak and M. K. Sarkar, 2008. Efficacy of different 
seed dressing agents in the control of damping off disease of chilli caused by Pythium aphanidermatum. $J$. Mycopathol. Res. 46 (1): 121-123.

Salman, M. and R. Abuamsha, 2012. Potential for integrated biological and chemical control of damping off disease caused by Pythium ultimum in tomato. Biocont. 57 (5): 711-718.

Sharma, P. and S. K. Sain, 2005. Use off biotic agent and abiotic compound against damping off of cauliflower caused by Pythium aphanidermatum. Indian Phytopathol. 58 (4): 395-401.

Sushir, M. A., R. N. Pandey, K. V. Sushir and S. Patil, 2006. Evaluation of Trichoderma harzianum against soilborne plant pathogens. PKV Res. J. 30 (1): 109-111.

Sushir, M. A., S. P. Patole and K. K. Suryawanshi, 2014. Evaluation of Trichoderma harzianum against soilborne plant pathogens. Trends in Biosci. 7 (9): 698-699.

Thakur, N. and A. Tripathi, 2015. Biological management of damping-off, buckeye rot and Fusariam wilt of tomato (cv.
Solan Lalima) under mid-Hill conditions of Himachal Pradesh. Agri. Sci. 6: 535-544.

Usharani, S., and G. Satheesh, 2007. Management of damping-off of tomato caused by Pythium aphanidermatum (Edson) Fitz. through biocontrol agents, organic amendments and soil solarization. $\mathrm{Pl}$. Dis. Res. 22 (1): 27-29.

Yadav, D. L. and K. R. Joshi, 2012. Efficacy of agrochemicals against Pythium aphanidermatum cause damping off in bidi tobacco. J. Pl. Dis. Sci. 7(1): 77-80.

Zagade, S. N., G. D. Deshpande, D. B. Gawade, A. A. Atnoorkar and S. V. Pawar, 2012. Biocontrol agents and fungicides for management of damping off in chilli. World J. Agril. Sci. 8(6): 590-597.

Zalte, A., R. M. Gade, A. V. Shitole and Y. K. Belkar, 2013. Management of damping off by using plant growth promoting microorganisms. $\mathrm{J}$. Pl. Dis. Sci. 8(2): 200-203.

\section{How to cite this article:}

Tekale, A. G., D.D. Guldekar, V.P. Kendre, A.P. Deshmukh and Potdukhe, S.R. 2019. Efficacy of Fungicides and Bioagents against Damping off in Chilli caused by Pythium aphanidermatum. Int.J.Curr.Microbiol.App.Sci. 8(06): 637-648. doi: https://doi.org/10.20546/ijcmas.2019.806.074 